\title{
Miscelánea
}

\section{De Leviatán al Toro de Wall Street}

\section{From Leviathan to Toro of Wall Street}

\author{
Enrique LUQUE BAENA \\ Departamento de Antropología Social y Pensamiento Filosófico Español \\ Universidad Autónoma de Madrid \\ enrique.luque@uam.es
}

Recibido: 21 de mayo de 2010

Aceptado: 24 de junio de 2010

\begin{abstract}
Resumen
¿Cual es en nuestros días el antagonista principal de la gran metáfora hobbesiana? En términos jakobsonianos, el Toro de Wall Street parece situarse mucho más próximo al polo metonímico que al metafórico. Alguien ha venido a equiparar el famoso Toro a Leviatán en un doble sentido: primero, porque ha venido a representar la autonomía de la economía - la fuerza de recuperación interna del mercado tras las fases bajistas de la bolsa-, del mismo modo que Leviatán representó la autonomización de la esfera política respecto a los controles eclesiásticos; y, en segundo lugar, porque como el Estado que encarna Leviatán termina por adquirir atributos sagrados, el Toro, que ha venido a identificarse con el mercado de valores, acaba por ser igualmente reverenciado.
\end{abstract}

Palabras clave: política, economía, religión, metáfora, metonimia.

\begin{abstract}
What is nowadays the main antagonist to the great Hobbesian metaphor? In Jakobsian terms, the Bull of Wall Street seems to be much closer to the metonymical pole than to the metaphorical one. Somebody have equated the famous bull to Leviathan in a dual sense: first, since it has come to represent the empowerment of economy, the strength of the internal recovery phase of the stock market after periodic turmoils, just as Leviathan represented both the state autonomy and its political independece from church control; and, secondly, because if the Leviathan State eventually acquired sacred attributes, the Bull has come too to be identified with the stock market and ending up beeing equally revered.
\end{abstract}

Keywords: politics, economics, religion, metaphor, metonymy.

Referencia normalizada: Luque Baena, E. (2011). De Leviatán al Toro de Wall Street. Revista de Antropología Social, 20, 333-346.

SUMARIO: 1. Introducción. 2. Historia de dos rupturas. 3. Lucha de dioses. 4. Conclusión. 5. Referencias bibliográficas. 


\section{Introducción}

En estas páginas hablo de política — bastante—, de economía —algo- - y de metáforas. Pero también de algo que, para mí, une todas estas cosas: de antropología. Por eso empezaré por un recuerdo. Es una anécdota personal que espero que ayude a entender mi interés por estos temas. Pues bien, hace ya muchos años y después de haber estudiado Derecho y de ser ya, en cierto modo, autodidacta en antropología, cursé estudios de esta materia de manera bastante más formal y rigurosa en el Reino Unido: el Departamento de Antropología Social de la Universidad de Manchester, que tenía fama en el mundo entero de ser pionero en el campo de la antropología política. Integrado hasta entonces en un departamento de Derecho Político, me interesaba dedicarme a partir de entonces al estudio antropológico de lo político, por lo que la elección mancuniana parecía la más adecuada. Sin embargo, una vez en Manchester no sé quién se sorprendió más: yo, al constatar con pesar que no se daban cursos de antropología política, o la buena gente del departamento, al saber que alguien estaba interesado en algo que sólo parecía existir para autores como George Balandier, creador a la sazón de un libro con ese título y panegirista de Max Gluckman y la llamada Escuela de Manchester, inspirada y liderada por él. Realmente, como pude comprobar bien pronto, nada era allí especificamente político porque todo - ritual, parentesco o economía - lo era. Mis papers para los exámenes versaron sobre temas tan diversos como las prohibiciones del incesto entre los tswana, la brujería de los azande o la hechicería de la isla de Dobu o los cultos cargo de Melanesia. Pero todos ellos se transmutaban, antes o después, en fenómenos políticos tal como los entendían los mancunianos. Fue, en definitiva, muy provechoso para mí aquel cuestionamiento de esas parcelaciones que nuestro mundo hace de la realidad. Y, desde entonces, no he dejado de moverme en esas coordenadas de una u otra forma. Pues bien, mi interés actual supone, en buena medida, una vueltas a aquellos años pero mirando hacia nosotros mismos y lo que nos rodea. $\mathrm{O}$, más bien la génesis de lo que nos rodea. Concretamente, lo que se relaciona con conceptos como política, economía o religión.

Vayamos ya al bosque de los símbolos, como llamó a su libro un famoso discípulo de Gluckman, Victor Turner. Para ello me olvido ya de Manchester para poder calificar al Leviatán de Hobbes como una imagen política y al Toro de Wall Street como un símbolo económico.

La imagen del Leviatán, como es bien sabido, figura en la portada de la edición original de la obra y ha seguido apareciendo en incontables ediciones de la misma, en todos los idiomas y hasta nuestros días. Tiene, pues, la respetable edad de 359 años. Representa, como también se sabe, al animal acuático que en la versión bíblica puede aludir a un cocodrilo, a una serpiente y, probablemente también, al terror que inspiraba en el imaginario judío el imperio egipcio. Su descripción pormenorizada aparece en el Libro de Job ${ }^{1}$ y a él corresponde la leyenda que figura en la parte superior de la portada: "Non est potestas Super Terram quae Comparatur eĩ".

\footnotetext{
${ }^{1}$ Sigo la edición de la llamada Biblia de Jerusalén (1967).
} 
En cuanto al Toro, — también llamado Charging Bull: en traducción libre, toro a punto de embestir o como digan los taurinos - es mucho más joven: apenas poco más de veinte años. El Toro fue instalado por su propio autor, el italoamericano Arturo di Modica, el 15 de diciembre de 1989, delante del edificio de la bolsa, confiscado por la policía y, ante la demanda ciudadana, emplazado dos manzanas hacia el sur, frente a Broadway.

\section{Historia de dos rupturas}

Dejemos por el momento estos iconos y hagamos un poco de historia, historia de hechos y de pensamientos. Mark Lilla, autor de uno de los estudios más penetrantes sobre la ruptura epistemológica que supuso el Leviatán de Hobbes (2007), nos dice algo muy interesante respecto a la situación que vivimos desde hace apenas una década:

En el siglo veinte todos pensábamos que conocíamos cuáles eran los términos básicos del debate político, de la preocupación política y del conflicto político: guerra, revolución, nacionalismo, clase, raza. En el siglo veintiuno parece que nos hubiéramos transportado hacia atrás, al mundo de los siglos dieciséis y diecisiete, donde las cuestiones que nos preocupan son las de razón y revelación, tolerancia, martirio y mesianismo político (Carnegie Council for Ethics in International Affairs //http:// www.cceia.org/resources/transcripts/0002.html/).

De modo significativo, lo que Lilla viene a resaltar en su brillante recorrido por el pensamiento político occidental —en el que abarca desde sus orígenes judeocristianos hasta los fundamentos filosóficos y teológicos de los totalitarismos del siglo XX - es algo en lo que la antropología ha venido insistiendo hace ya muchas décadas. Esto es, que lo europeo u occidental no constituye la única cosmovisión política posible. Otras obras igualmente recientes, a cargo de historiadores algunas de ellas, ponen igualmente de relieve cómo los modelos — políticos, económicos, religiosos - occidentales no pueden postularse como universales y generalizables a todo el orbe, por más que ese haya sido el intento - y en buena medida el logrode Occidente.

Fue significativamente una concepción precristiana de la divinidad la que coadyuvó a la ruptura. Se trata de la noción epicúrea que sitúa el origen de la religión en la ignorancia: el miedo al sufrimiento acarrea la esperanza en dioses que nos liberen de nuestros males. Como resume Emilio Lledó (2003: 69), "los dioses son invención nuestra; fruto de nuestras necesidades, de nuestras frustraciones, de nuestros deseos". Ahora bien, subraya Lilla, Hobbes era un epicúreo moderno. El antiguo epicureismo constituía un movimiento espiritual que anhelaba la consecución de la vida privada feliz. El moderno, en cambio, tiene una clara finalidad política: desmantelar el complejo teológico-político cristiano. Concebida, pues, la religión como fruto tanto de la ignorancia como del miedo, queda otro elemento por definirla: su carácter estrictamente humano: "Viendo que no hay signos ni frutos de la religión sino en el hombre exclusivamente, no hay causa para poner en duda que la semilla de la religión está exclusivamente en él y consiste en alguna cualidad peculiar o al 
menos en algún grado eminente de la misma, que no se encuentra en otras criaturas vivas" (Hobbes, 1979: 208). Además, el ciclo perverso no termina con la invención de los dioses, sino que una vez creados se convierten a su vez en fuente de terror. Peor aún, el miedo a los dioses es paralelo al miedo a otros hombres. El hombre no es naturalmente político; no colabora o se asocia espontáneamente con otros hombres, sino que es lobo para sus semejantes. De ahí que, como resalta Lilla, Hobbes sea el primer pensador en plantear que conflicto político y conflicto religioso son uno y el mismo: "un único ciclo político-teológico de violencia, fanatismo, superstición y terror paralizante".

El autor de Leviatán profundiza el tajo entre animales y hombres al subrayar que la violencia en unos y otros tiene un carácter muy diferente justamente debido a la religión: los primeros sólo luchan para sustentarse y reproducirse, los segundos para alcanzar el paraíso. Es algo en lo que concuerda con el viejo epicureismo: "si un dios hiciera caso a las súplicas de los hombres, pronto todos ellos acabarían destruyéndose, porque continuamente están deseándose múltiples males los unos a los otros" (Lledó, 2003: 68). Claro está que, aunque formulado en términos genéricos, el ataque hobbesiano va dirigido a los conflictos religiosos acarreados por Reforma y Contrarreforma. Y el propósito de toda su arquitectura retórica tiene un objetivo y un foco: el soberano. Más exactamente, es un soberano absoluto que pudiera asegurar que sus súbditos no temieran a otro soberano, divino o humano, más que a él y "así la paz podría ser posible. Por eso es por lo que Hobbes lo llama un Dios terrenal". De ese modo, hace hincapié Lilla, después de más de un milenio de teología política cristiana, Hobbes descubre una forma radicalmente nueva para reflexionar sobre religión y bien común sin apelar al nexo entre Dios, hombre y cosmos. Es una vía que no refuta sus fundamentos revelados pero los hace irrelevantes. Son irrelevantes porque el otro propósito de Leviatán es aplicar a este terreno las conquistas de las nuevas ciencias, separar la pesquisa intelectual del control eclesiástico medieval, reformar en suma la filosofía y la ciencia rescatándolas así del Reino de la oscuridad. A un universo natural, moralmente neutro y separado de su creador, corresponde una vida política cuyas únicas referencias son humanas. Es una separación a la que cuadra también otra de enorme importancia en la modernidad y en el pensamiento político poshobbesiano: la distinción entre culto público y privado. Ello supone dejar en manos del soberano la facultad y el derecho a organizar los rituales colectivos y externos, pero sin poder inmiscuirse inquisitorialmente en el terreno de las conciencias.

Sin embargo, lo que parece que adquiere vigencia en estos últimos años es una revisión profundamente crítica de lo que se ve ya claramente como una artificiosa y nunca conseguida desmembración de lo político, lo económico y lo religioso en el propio mundo occidental. Todo esto se encuadra, más bien, en el mito del progreso de la Ilustración del siglo XVIII, en el evolucionismo spenceriano del XIX o en la teoría de la modernización del siglo $\mathrm{XX}^{2}$. Mitos todos ellos que siguen plenamente vigentes entre nosotros y que se manifiestan de muchas maneras y en los más

\footnotetext{
${ }^{2}$ Lo ponen de relieve, por ejemplo, Fitzgerald (2007) y Kaplan (2007).
} 
diversos contextos. Por ejemplo, entre tertulianos que, sin el menor conocimiento respecto a la radical modernidad del fundamentalismo islámico, pontifican sobre el confinamiento del islam en la Edad Media. O en la sorpresa que provoca el ver unidas las nuevas tecnologías con el universo mágico africano. $\mathrm{O}$ en el impacto que nos puede causar - ha sido mi caso - el constatar como simples turistas la fuerza de resistencia revolucionaria de la sangha, la comunidad budista, frente a la brutalidad represora de la junta militar de Miamar.

Que todo esto era así poco más allá de nuestras fronteras no es novedoso para la antropología. Lo nuevo es que lo de aquí mismo comience a contemplarse no ya como excepcional, sino como constatación de que el deslindamiento de esas articulaciones de lo real nunca se ha producido plenamente más que en los esquemas mentales de los filósofos y teóricos de la política, en los textos legales y constitucionales y, a lo más, en determinados sectores ilustrados de nuestras sociedades. Es triste comprobar cómo desde la Carta sobre la tolerancia de John Locke (1689), de 1669, trascurre casi un siglo para que Voltaire denuncie, en 1766, el fanatismo religioso en la Francia ilustrada en su Traité sur la tolérance (1769), escrito con ocasión del asesinato legal del hugonote Jean Calas. Pero el mismo proceso de deslindamiento conceptual fue bastante lento y no poco azaroso. Por ejemplo, el término político no se introduce en la literatura europea con un sentido algo parecido al actual hasta el siglo XIII, gracias a la traducción latina de la obra de Aristóteles — no sólo la Política, sino la Ética nicomaquea también-; pero, precisamente por influencia aristotélica, el término queda confinado a un tipo de régimen político: el democrático, con arreglo a los criterios de la época (Rubinstein, 1990). En cuanto al término religión o religioso, ocurre algo parecido. Pensemos que la idea plural — las religiones de la tierra - es bastante tardía ${ }^{3}$. Así, en la España del siglo XVI se habla, al aludir a los moriscos, de la secta de Mahoma, no de la religión del islam. Hay, por tanto, una sola religión y lo demás son desviaciones. Paradójica, y tal vez significativamente, el término religión aparece con escasa frecuencia en una situación en que la religión lo es todo, ya que le concierne por igual la consecución de la salvación del alma y del orden social. Y, por supuesto, esto no ocurre sólo aquí. En la Inglaterra, ya anglicana y antipapista, viene a decirnos el historiador Timothy Fitzgerald, donde impera igualmente esa indistinción terminológica, el discurso dominante de la época concibe como análogos el orden del cosmos, el del Estado y el de la familia: las medidas de gobierno se anuncian rutinariamente en las iglesias y los obispos desempeñan papeles importantes en el parlamento y en la corte ${ }^{4}$.

Lilla atribuye apropiadamente a Hobbes la responsabilidad de ruptura de ese cosmos social y teológico, fractura a la que denomina la Gran Separación. Lo venido después, según este autor, no es más que la consecuencia de ese foso abierto entre lo religioso y lo político, la ciencia y la fe y otras dicotomías por el estilo.

\footnotetext{
${ }^{3}$ Ver Fitzgerald (2007) y sobre todo Masuzawa (2005).

${ }^{4}$ Según Joan Corominas (1990), también en castellano los significados actuales de política y religión son relativamente tardíos: política equivalía a finales del siglo XIV a "buena crianza"; religioso equivalía en la misma época a "monje", mientras que religiosidad es término de finales ya del siglo XVII.
} 
Consecuencia de la ruptura, bien para suavizar el autoritarismo hobbesiano, bien para tratar de recuperar la solidez o estabilidad del viejo sustrato teológico, ha sido toda la teorización filosófico-política posterior, que en ningún caso ha refutado lo esencial de esa fractura. En las secuelas de la Gran Separación entran cosas heterogéneas que van, por ejemplo, desde los retoques liberales de Locke y Hume a la teología política — roussoniana y kantiana — basada estrictamente en la experiencia y la razón humanas. Aunque también podríamos incluir todo ese decurso histórico, trazado hace años por George Mosse en La nacionalización de las masas, y que abarca desde los rituales aparentemente blasfemos de la Revolución Francesa hasta la refundación del panteón germánico en la génesis del nazismo (Mosse, 2005).

La obra de Lilla no es un estudio de acontecimientos históricos, sino de filosofía política. Por eso no aborda en ella lo que constituye el trasfondo sociocultural de Leviatán, esto es, las guerras de religión que trajeron consigo en Europa Reforma y Contrarreforma. Leviatán tiene una clara finalidad política en un sentido moderno y es, por tanto, una obra claramente antirreligiosa - y subrayo anti en sentido estrictamente etimológico: en lugar de, sustituyendo a algo-. Pretende desmantelar el complejo teológico-político que había imperado en Europa desde la era de Constantino. Para ello presenta la religión como obra humana, pero no precisamente beneficiosa para el hombre, ya que los dioses se convierten en fuente de miedo para sus creadores humanos ${ }^{5}$ : quienes, además, se tienen miedo entre ellos y se convierten en lobos para sus semejantes. Es peor aún: porque los animales sólo luchan para reproducirse mientras que los hombres lo hacen para alcanzar el paraíso, lo cual es obviamente mucho más peligroso. ¿Cómo salir de ese laberinto, de esa condición miserable que constituye la naturaleza humana y "que acompaña a la libertad de los hombres particulares", en expresión de Hobbes? Ahí es donde entra en juego el soberano, el ente colectivo o dios terrenal que es Leviatán, formado por esos homúnculos que aparecen en el grabado de portada de las muy diversas ediciones de la obra. Leviatán, que es la aplicación directa de la ciencia a la política, proporciona seguridad, aunque eso sí, a costa de aquella libertad que tenían los individuos aislados para matarse unos a otros.

A un universo moralmente neutro corresponde, también, una vida social que diferencia tajantemente lo público y lo privado. Al soberano corresponde el derecho a organizar rituales colectivos y externos, sin poder inmiscuirse, por el contrario, en las conciencias. Y observa Lilla: (2007: 90) "La esperanza y la expectativa de Hobbes es, obviamente, que a medida que el miedo y la credulidad decrezcan con el tiempo, los hombres y mujeres modernos tengan menos necesidad de religión —una necesidad que podrán satisfacer privadamente en tanto que no entren en el espacio público-"."

La separación entre público y privado, política y religión no tenía, por otra parte, un puro interés epistemológico. Como ha señalado algún otro autor, tal separación favorecía los intereses comerciales en ultramar de algunos de los más ardientes defensores de la misma. Tal fue el caso de John Locke, con clara implicación en

\footnotetext{
${ }^{5}$ Sigo la edición española de Leviatán preparada por Moya y Escohotado (1979).
} 
actividades mercantiles en las colonias de América del norte. Otros, menos famosos que Locke, pero igualmente propugnadores de la separación entre Iglesia y Estado, una vez establecidos en colonias, como ocurrió en la bahía de Massachussets, prohibieron cualquier disidencia en su territorio (Fitzgerald, 2007).

Por otra parte, la Gran Separación pretendió también abrir otro abismo entre el pasado, más o menos remoto, y la modernidad. La Ilustración primero y el evolucionismo social después profundizarían aún más esa fosa. El pasado se imaginó como época de sacrificios sangrientos, de los cuales las guerras de religión venían a ser reminiscencias atávicas. Este abismo se trasladó del tiempo al espacio, es decir, a los grupos humanos más ajenos y lejanos de Europa (Kaplan, 2007). No es causalidad ni mucho menos que la única referencia empírica con la que Hobbes ilustra el lamentable estado de naturaleza humano sea, en el capítulo XIII, "las gentes salvajes de muchos lugares de América". Es una alusión, qué duda cabe, marginal, genérica y absolutamente carente de rigor para los parámetros de la etnografía contemporánea. Pero resulta antecesora de la identificación posterior entre el tiempo felizmente superado y el espacio altivamente despreciado.

Y para estas actitudes no importa mucho que las mutaciones que propugnaban los textos de Hobbes o de Locke tardaran en plasmarse en textos constitucionales. Tampoco importa demasiado que tales mutaciones fueran más aparentes que reales. En este sentido, resulta paradójico que el gran hallazgo de la modernidad política, las constituciones escritas, adquirieran pronto un valor sagrado. Y, por supuesto, también sus artífices. Por ejemplo, un heredero de los primeros puritanos norteamericanos y que fue el segundo presidente de Estados Unidos, John Adams, comparó críticamente la idealización de George Washington con la canonización de los santos y "otras prácticas corruptas de un pasado supersticioso". Pero no pudo evitar que su sucesor y eterno rival, Thomas Jefferson fuera venerado a su muerte como una especie de Cristo, ni que las viviendas de los padres de la constitución se convirtieran hasta hoy en auténticos santuarios y centros de peregrinación (Fitzgerald, 2007).

El desgajamiento de la esfera política respecto a la religiosa ha servido como precedente y modelo de otro no menos importante. Me refiero al que se produjo bastante después entre política y economía. Hasta muy avanzado el siglo XVIII, incluida la época de Adam Smith, economía mantuvo su significado originario y, por tanto, relativo al ámbito privado o doméstico. La misma economía política fue concebida como mera extensión al ámbito estatal de contextos y significados domésti$\cos$. La neta separación entre ambos dominios, político y económico, llegaría más tardíamente, con clara influencia de Smith, pero de la mano de Bentham y Ricardo. La ausencia deliberada de filosofía social en Ricardo y el más bien alicorto pragmatismo y utilitarismo de Bentham hacen muy diferente en magnitud la ruptura, si la comparamos con las dimensiones de la Gran Separación hobbesiana (Sabine, 1965). Pero las consecuencias, en cambio, han sido tal vez de mucho mayor calado. Como resaltó Carl Schmitt (1963) en su demoledora crítica de las consecuencias liberales de la revolución de Hobbes, lo que hoy supone la economía y sus ciclos es análogo a lo que hasta hace poco más de doscientos años significaba el mundo natural y sus catástrofes. Escribe al respecto: 
El terremoto de Lisboa del Siglo XVIII... provocó toda una inundación de literatura moralizante mientras que hoy un acontecimiento similar no tendría consecuencias intelectuales profundas siendo que, por el contrario, una catástrofe en la esfera económica, una gran devaluación o un colapso financiero, despiertan el interés activo no sólo práctico sino también teórico de los más amplios estratos.

Dicho en términos más cercanos a nosotros, lo que produjo la ideología económica vino a suponer un giro cultural de cuyas consecuencias aún vivimos hoy en día. Ha sido, por otra parte, Louis Dumont quien ha recalcado el gran contraste entre lo que denomina el artificialismo de la especulación política a partir de Hobbes con este otro ámbito: "La consideración económica — nos dice - se constituirá mucho más como una ciencia natural, estudiándose en ella lo que ocurre en el mundo exterior como un fenómeno natural" (Dumont, 1982: 88; las cursivas son mías). Y más adelante insiste en la misma idea: "la emancipación del dominio económico exigía que fuera considerado como la arena en que actuaban leyes naturales, de tal forma que la intervención humana sólo podía resultar perjudicial" (Dumont, 1982: 212).

\section{Lucha de dioses}

Quiero recalcar ese contraste entre artificialidad y naturaleza. Y con esto volvemos al bosque de los símbolos. Tal vez la forma más expeditiva de tratar con metáforas sea la de un notable estudioso de las mismas. Me refiero a Colin M. Turbayne, quien en su hoy clásico The myth of metaphor (1962) nos dice que su uso implica nada menos que la pretensión de que algo es algo cuando en realidad no lo es. Usar una metáfora conlleva necesariamente hacerlo a sabiendas de que aquello que llamamos $\mathrm{X}$ no es realmente $\mathrm{X}$. A lo que apunta este autor es al riesgo de desaprovechar el valor explicativo de las metáforas tomando por realidad lo que constituye su representación. Es algo que, en sus casos extremos, analizó Jakobson (1956: 76 y ss.) como trastornos de lenguaje y la fijación exclusiva del afásico en los polos metafórico o metonímico. Umberto Eco, que une a su condición de semiólogo la de escritor de novelas, nos ha dejado en una de ellas una vívida descripción de lo que nos impide traspasar el umbral de la locura:

esa lucidez intelectual que nos permite distinguir siempre entre lo similar y lo idéntico, entre la metáfora y la cosa, esa facilidad misteriosa y fulgurante y bellísima que siempre nos permite decir, por ejemplo, que fulano es un animal sin pensar en absoluto que le ha crecido pelo por todo el cuerpo y que le ha salido una cola, mientras que el enfermo piensa "es un animal" y enseguida se imagina que el individuo en cuestión ladra, gruñe, repta o vuela (Eco, 1997: 600).

¿Por qué no olvidarnos, entonces, de las metáforas? Sencillamente, porque no podemos hacerlo. Por supuesto, no me refiero a las que constituyen, como cualquier otro tropo, un elemento de ornato en el discurso; y que pueden ser mejores o peores, originales o repetidas hasta la saciedad. De esas sí podríamos prescindir, a riesgo sólo de hacer un discurso plano, casi pedestre. El problema es que otras muchas - esas que llamaron Lakoff y Jonson metaphors we live by, metáforas con las 
que convivimos - forman parte imprescindible de nuestro lenguaje y apenas somos conscientes de que las usamos. Por otra parte, tampoco podemos dejar de usar metáforas en ningún campo del conocimiento, como bien recalcaba el matemático y semiólogo Max Black: "toda ciencia debe empezar con la metáfora y terminar con el álgebra; pero quizá sin la metáfora nunca habría existido el álgebra"\%.

En el ámbito de la política —y también por supuesto en el de la economía- las metáforas no son aparentemente tan imperceptibles como las que nos sirven para referirnos a las dimensiones espacio-temporales; aunque de todo hay; entre otras cosas, porque prácticamente todo el léxico de la política, empezando por esta misma palabra, se acerca en mayor o menor medida al polo metafórico o metonímico. Para empezar, y como ya nos ilustró hace años la antropóloga Mary Douglas, el vehículo metafórico más cercano que tenemos y el que más usamos es nuestro propio cuerpo. Convertido en representación del cuerpo social, nos lo encontramos en lugares tan diversos como los rituales ancestrales africanos o en el cuerpo místico que simboliza tanto la unión de Cristo con su Iglesia como, en la monarquía tradicional, la comunión que, como institución, forma el rey con otras instituciones, como el Parlamento? Es una metáfora reversible, porque la inmunología adopta símbolos políticos-militares —ataques, defensas, zonas invadidas, etc.- para referirse al cuerpo humano ${ }^{8}$. Según subraya Susan Sontag (1978):

La enfermedad como metáfora del desorden político es una de las más antiguas nociones de la filosofía política. Si es plausible comparar la polis a un organismo, es igualmente plausible comparar el desorden civil a una enfermedad. Y las formulaciones clásicas que hacen análogo el desorden político y la enfermedad — desde Platón a Hobbes, por ejemplo — presuponen la idea clásica médica (y política) de equilibrio. La enfermedad procede del desequilibrio. El tratamiento va dirigido a restablecer el equilibrio adecuado —en términos políticos, la jerarquía adecuada- . El pronóstico es siempre, en principio, optimista. La sociedad nunca coge una enfermedad fatal.

Ahora bien, las metáforas políticas, como todas, obedecen a concepciones y cosmovisiones que cambian con el tiempo. Así, la idea de naturaleza que subyace a los planteamientos platónicos no es idéntica a la de Hobbes. Como mostró Collinwood en su La idea de naturaleza, la unidad de todo lo viviente que caracteriza al universo griego se rompe en el universo moderno, o más exactamente barroco. Impera por el contrario la dualidad de mente y cuerpo cartesiana. La naturaleza deja de concebirse como ente vivo para hacerse equivalente a una máquina que la mente divina ha construido. Llevando esto al terreno de la política, la metáfora estriba en concebir el Estado como puro artificio humano; es decir, Leviatán.

El Barroco, a diferencia del Renacimiento, no fue precisamente muy amigo de la palabra, pero sí de la imagen. Nuestra literatura del Siglo de Oro, sea satírica, moral

\footnotetext{
${ }^{6}$ Citado por Denis Donoghue (1969).

${ }^{7}$ Me refiero al conocido estudio de Ernst H. Kantorowicz, The king's two bodies. A study in mediaeval political theology.

${ }^{8}$ Ver, por ejemplo, Emily Martin (1990).
} 
o política (Quevedo, Gracián o Saavedra Fajardo) está repleta de denuestos contra las filigranas de las palabras y de elogios del silencio (Luque, 2002). Hobbes no está alejado en absoluto de ese espíritu. Por cuatro veces nada menos, en sólo dos capítulos de Leviatán, el IV y el V, censura acremente el empleo de las palabras usadas como metáforas y, en la última ocasión, llega incluso a equipararlas con las palabras ambiguas y sinsentido y todas ellas con fuegos fatuos.

Y, sin embargo, desde la primera página, Leviatán es pura metáfora. Así comienza la obra: "La Naturaleza (Arte con el cual Dios ha hecho y gobierna el mundo) es imitada por el Arte del hombre en muchas cosas y, entre otras, en la producción de un animal artificial'".

Y la cumbre de ese arte humano es "ese gran Leviatán que se llama una república o Estado". Uno pensaría que el monstruo bíblico que le sirve de referente se nos presenta ya como poco natural. Está hecho, nos dice el Libro de Job de "hileras de escudos"; y también leemos allí que su potencia es descomunal: "Para él el hierro es sólo paja, el bronce madera carcomida".Y para rematarlo todo, la frase que encabeza la portada del libro: "Nada hay sobre la tierra que pueda comparársele"10.

Como ya apuntara Michael Walzer, Hobbes seguía toda una línea iniciada con la Reforma y que cuestionaba seriamente todo el simbolismo, jerárquico y orgánico, medieval y tradicional. Así, Martín Lutero atacaba al autor medieval Dionisio, que había elaborado los símbolos jerárquicos y, censurándolo por jugar con alegorías y no con realidades, decía que esto era algo en lo que se ocupaban quienes no tenían algo mejor que hacer. Esa línea incluye a Bacon y, por supuesto, a Hobbes, quien, en el pensamiento político, desarrolló una guerra parecida contra el simbolismo, defendiendo una concepción estrecha del lenguaje y prometiendo una ciencia libre de los absurdos de la metáfora. Sin embargo, paradójicamente, tanto la nueva ciencia como la vieja cosmología, más que un conjunto de proposiciones, lo que proporcionan es todo un conjunto de imágenes impactantes y sugestivas que sustituyen a las antiguas. Así, frente al cuerpo político medieval, ofrece el cuerpo en movimiento de la nueva física; frente a la integración armónica, la anarquía de movimiento; frente a la autoridad, el poder; por último, frente al crecimiento, la construcción. Y frente a los viejos ídolos, Leviatán: “Al fin y al cabo, ¿qué es Leviatán — 'ese dios mortal' y máquina perfecta- sino un nuevo Ídolo?" (Walter, 1962).

Volvamos ahora por un momento al contenido de la obra hobbesiana. Las ilustraciones de la portada de Leviatán describen lo que sintetizan las palabras del subtítulo: A Commonwealth ecclesiaticall and civil. A la izquierda, los elementos cívico-militares; a la derecha, los eclesiásticos. Todo está presidido por el gran artificio de Leviatán, que reúne, uno en cada mano, los símbolos de ambos poderes: la espada y el báculo.

Hobbes dedica todo un capítulo de su libro, el XLII, titulado Del poder eclesiástico, a propugnar la supremacía del poder terrenal; ante todo, a sepultar definitivamente el poder supremo del pontífice romano, el vestigio de la teología política medieval. Frente al argumento de que lo temporal depende de lo espiritual y está sometido a él,

${ }^{9}$ Sigo la edición española citada. Las cursivas son mías.

${ }^{10}$ Biblia de Jerusalén, ya mencionada. 
argumenta Hobbes lo siguiente: no existe una sola república, sino que "es evidente que Francia es una República, España otra y Venecia una tercera", porque lo que quiere dejar claro desde el principio es que, fiel al texto evangélico, "el reino de Cristo no es de este mundo". Por tanto, ninguno de sus ministros puede exigir algo que vaya contra una orden del rey o de cualquier otro representante de la república. De ahí que la excomunión de un soberano o de un súbdito cristiano que siga sus leyes no tiene ningún efecto. "Cristo nuestro Salvador - dice rozando el sarcasmo- envió a sus discípulos como corderos a los lobos, no como reyes a sus súbditos".

Toda metáfora conlleva, etimológicamente incluso, una transferencia de significado $y$, en definitiva, una apertura del universo del discurso. Nos permite trasladarnos del mundo que conocemos y que quizá detestamos a lo que es desconocido pero admiramos o deseamos. Máxime, pensaría uno, si las metáforas son tan hiperbólicas como las hobbesianas, comenzando por el artificio que encabeza la portada y ocupa páginas de Leviatán. Hay quien, refiriéndose precisamente al lenguaje político, sitúa la metáfora en los discursos y programas políticos que proponen cambios, mientras asignan la metonimia a la defensa del status quo. Hay que tener en cuenta que, con arreglo al estudio de Jakobson, metáfora y metonimia no son, como él dice, atributos exclusivos del "arte verbal", sino propios de cualquier otro sistema semiótico. En ese sentido, el propio Jakobson se refiere a la alternancia artística de la orientación metonímica del cubismo, contestada por una actitud decididamente metafórica del surrealismo.

\section{Conclusión}

¿Qué se contrapone a la gran metáfora hobbesiana? Me parece ver en el Toro de Arturo di Modica algo que se acerca mucho más al polo metonímico que al metafórico. Hay quien ha equiparado el famoso Toro al Leviatán en un doble sentido ${ }^{11}$ : primero, porque ha venido a representar la autonomía de la economía - la fuerza de recuperación interna del mercado tras las fases bajistas de la bolsa-, del mismo modo que Leviatán representó la autonomización de la esfera política respecto a los controles eclesiásticos; y, en segundo lugar, porque como el Estado que encarna Leviatán termina por adquirir atributos sagrados, el Toro que ha venido a identificarse con el mercado de valores acaba por ser igualmente reverenciado.

Todo eso es bien cierto. Sin embargo, creo que las diferencias entre uno y otro icono no son menos importantes. Ante todo, no está nada claro que la intención del escultor Arturo di Modica — que impactó a los neoyorkinos colocando por sorpresa la estatua del Toro en vísperas navideñas - quisiera expresar todo lo que el Toro simboliza hoy en día. Más bien parece que, según manifestó en un principio, la figura evocaba la fortaleza del pueblo americano tras el crash bursátil de octubre de 1987. A diferencia de la metáfora hobbesiana, que anuncia una ruptura radical con el pasado - y que, como todas las metáforas, nunca acaba de realizarse plenamente-, el Toro se vincula estrechamente, por contigüidad, como el tropo metonímico, tanto con el pasado inmediato — la crisis bursátil — como con el espacio — el edificio de la bolsa junto al que permaneció poco tiempo-. Además, el artificio de Hobbes trata de romper

\footnotetext{
${ }^{11}$ Concretamente lo hace Timothy Fitzgerald (2007).
} 
con la naturaleza, donde existe esa condición miserable de los individuos humanos sometidos a los miedos religiosos. En cambio, el Toro, dotado de significado con el tiempo, viene a encarnar la fuerza brutal de la naturaleza que ningún artificio humano o estatal puede ni debe controlar ${ }^{12}$. El Leviatán está hecho de hombres y por hombres y es temporal, puede perecer; precisamente el gran miedo de Hobbes es que perezca, que se produzca la contienda civil, es decir, la vuelta a la naturaleza. El Toro, fuerza de la naturaleza, es casi atemporal y queda a salvo de las manipulaciones humanas. La mano invisible de Adam Smith tiene, por fin, un rostro bien visible y no poco agresivo. Por más que los toros más bravos — como sabemos en nuestro país - son resultado de largos y costosos procesos de selección que poco o nada tienen de natural. Lo malo es que parece que el propio léxico político comienza a contagiarse de naturalismo: desde hace un tiempo se oye hablar, por ejemplo, de tsunami para referirse a conmociones electorales o escándalos de financiación ilegal — lo empleó Gaspar Llamazares para referirse al bipartidismo triunfador en las elecciones generales anteriores; y lo ha empleado José Blanco para hablar del caso Gürtel - . No hace tanto, todavía usábamos términos como rodillo parlamentario. Al fin y al cabo, un término más mecánico; es decir, más político.

Werner Sombart, que historió el capitalismo en su obra El capitalismo moderno, restringía la pretendida equiparación entre racionalidad y capitalismo a una de las etapas de su desarrollo y no, por supuesto, a lo que ha ocurrido después de la ya lejana Primera Guerra Mundial (Bell, 1976). Tal vez hemos tardado demasiado tiempo, más de doscientos años, desde la publicación de La riqueza de las naciones, en ver la realidad con su auténtica faz y en llamar a las cosas por su nombre.

Claro que se trate de metáfora o de metonimia, el destino de las imágenes que representan el Leviatán y el Toro parece ser idéntico: terminar sacralizadas como los viejos ídolos a los que pretendieron suplantar. Una crónica de un periódico norteamericano de hace un par de años relata un día de paseo por los alrededores del Charging Bull y nos cuenta cómo turistas de todo el mundo contemplan, se fotografian o hacen bromas junto al Toro. La escultura es hoy uno de los iconos más famosos de Nueva York, casi como la Estatua de la Libertad o el Puente de Brooklyn. El cronista capta una instantánea curiosa: un chico venezolano ha trepado a los cuernos del Toro en el momento en que unos hombres de negocios chinos tratan de hacer unas fotos de animal. Los chinos miran con visible irritación al osado y tal vez blasfemo muchacho. Y a uno le queda la duda de si esos empresarios, ellos mismos o sus padres, no formarían parte, no hace tantas décadas, de los millones de chinos que aclamaban con entusiasmo al Gran Timonel, al camarada Mao Tse Tung.

${ }^{12}$ Es interesante ver cómo el columnista conservador, David Brooks, contrapone en The NewYork Times (18/1/2010) la metáfora de Leviatán con la energía espontánea de la sociedad americana: "Cuando los Peregrinos dejaron Gran Bretaña para venir a América, dejaron atrás también la metáfora [de Leviatán]. Para aquellos colonos, y para los inmigrantes que han venido desde entonces, la nación americana no es un cuerpo con el gobierno como cerebro. En lugar de eso, América se ha definido por su vasto paisaje y la desmadejada energía de sus empresarios, científicos y creadores de comunidades". 


\section{Referencias bibliográficas}

BELL, Daniel

1976 El advenimiento de la sociedad post-industrial. Madrid: Alianza Editorial.

BIBLIA DE JERUSALÉN

1967 Biblia de Jerusalén. Bilbao: Desclée de Brouwer.

COROMINAS, Joan

1990 Breve diccionario etimológico de la lengua castellana. Madrid: Gredos.

DONOGHUE, Denis

1969 "Parts of speech". The New York Review of Books, 12, 3 [13 de febrero].

DUMONT, Louis

1982 Homo aequalis. Génesis y apogeo de la ideología económica. Madrid: Taurus Ediciones.

ECO, Humberto

1997 El péndulo de Foucault. Barcelona: Plaza \& Janés.

FITZGERALD, Timothy

2007 Discourse on Civility and Barbarity. A Critical History of Religion and Related Categories. Oford, New York: University Press.

HOBBES, Thomas

1979 Leviatán. Madrid: Editora Nacional.

JAKOBSON, Roman; HALLE, Morris

1956 Fundamentals of language. The Hague: Mouton.

KANTOROWICZ, Ernst H.

1975 The king's two bodies. A study in mediaeval political theology. Princeton: Princeton University Press.

KAPLAN, Benjamin J.

2007 Divided by Faith. Religious Conflict and the Practice of Toleration in Early Modern Europe. Cambridge: The Belknap Press of Harvard University Press.

LILLA, Mark

2007 The Stillborn God. Religion, Politics, and the Modern West. New York: Alfred A. Knopf.

LLEDÓ, Emilio

2003 El epicureismo. Madrid: Taurus.

LOCKE, John

1689 A Letter Concerning Toleration by John Locke. Online Library of Liberty. Translated [from Latin] by William Popple. 
LUQUE BAENA, Enrique

2002 "De la palabra al silencio: Variaciones en el tiempo", en La sociedad: Teoría e investigación empírica. Madrid: CIS, 947-964.

MARTIN, Emily

1990 "Towards an anthropology of immunology: The body as nation state". Medical Anthropological Quarterly, 4, 4: 410 y ss.

MASUZAWA, Tomoko

2005 The invention of world religions. Or how European universalism was preserved in the language of pluralism. Chicago, London: The University of Chicago Press.

MOSSE, George L.

2005 La nacionalización de las masas. Madrid: Marcial Pons.

MOYA, Calos; ESCOHOTADO, Antonio (Eds.)

1979 Leviatán/Thomas Hobbes. Madrid: Editora Nacional.

RUBINSTEIN, Nicolai

1990 "The history of the word politicus in early-modern Europe", en Anthony Pagdem (ed.), The Languages of Political Theory in Early-Modern Europe. New York: Cambridge University Press, 41 y ss.

SABINE, George

1965 Historia de la teoría política. México: Fondo de Cultura Económica.

SCHMITT, Carl

1963 [1932] El concepto de lo político [Texto con un Prólogo y tres Corolarios, traducido de la edición de 1963 por Dénes Martos]. www.laeditorialvirtual. com.ar.

SONTAG, Susan

1978 "Disease as political metaphor". The New York Review of Books, 25, 2 [23 de febrero].

TURBAYNE, Colin M.

1962 The Myth of Metaphor. New Haven, London: Yale University Press.

VOLTAIRE [AROUET, François Marie]

1769 Traité sur la tolérance. À l'occasion de la mort de Jean Calas. Édition HTML: Pierre Cohen-Bacrie.

WALTER, Michael

1962 "On the role of symbolism in political thought". Political Science Quaterly, LXXXII, 2:191-204. 